\title{
Trends in Employee Ownership in Eastern Europe
}

\author{
Mygind, Niels
}

Document Version

Final published version

Publication date:

2007

\section{License \\ CC BY-NC-ND}

Citation for published version (APA):

Mygind, N. (2007). Trends in Employee Ownership in Eastern Europe. CEES, Copenhagen Business School. Working Paper / Center for East European Studies. Copenhagen Business School No. 68

Link to publication in CBS Research Portal

\section{General rights}

Copyright and moral rights for the publications made accessible in the public portal are retained by the authors and/or other copyright owners and it is a condition of accessing publications that users recognise and abide by the legal requirements associated with these rights.

\section{Take down policy}

If you believe that this document breaches copyright please contact us (research.lib@cbs.dk) providing details, and we will remove access to the work immediately and investigate your claim. 


\section{CEES}

Working Paper No. 68

December 2007

\section{Trends in Employee ownership in Eastern Europe}

Niels Mygind

nm.cees@cbs.dk

Center for East European Studies

Department of International Economics and Management

Copenhagen Business School

Porcelænshaven 24

Dk-2000 Frederiksberg, Denmark

$\mathrm{Tel}+4538152515 \quad$ Fax +4538152500 


\section{Trends in Employee ownership in Eastern Europe}

Niels Mygind, Center for East European Studies, INT, Copenhagen Business School

\section{Introduction and method}

In countries like Italy, France, Spain and US enterprises where a broad group of the employees have controlling ownership have been quite widespread, while the Scandinavian countries have had few employee owned enterprises. In many countries in Eastern Europe the recent privatization process resulted in a strong wave of employee ownership, however, a wave that soon lost its momentum. The transition from plan to market has been a sort of experiment for analyzing the impact of institutional development. The spread of employee ownership is closely related to the change in both formal and informal institutions. The purpose of this article is to answer the following research questions: Why did employee ownership get so widespread in some countries Eastern Europe? Why did this ownership change relatively fast to other types of ownership? Was the development of employee ownership premature in relation to the development of the East European societies?

The following analysis focuses on the ten new East European members of EU plus the applicant, Croatia. These countries were analyzed in a new report on the conditions for employees financial participation in enterprises in the new member states - The PEPPER III Report, (Lowitzsch, 2006). The following analysis gives first and overview over different forms of employee participation in ownership. Some of these forms such as profit-sharing and worker cooperatives are not widespread in Eastern Europe. Therefore, this analysis focuses on enterprises where a broad group of employees own the controlling ownership in the company. The following theoretical section explains factors promoting and hindering employee ownership. This is done both at the society-, enterprise- and individual levels and related to the specific conditions arising in transitional economies. The following section gives an overview over the specific developments in each country with focus on conditions explaining the rise and fall of employee ownership. These processes vary much between the countries and there are big differences in the coverage and quality of the relevant data. Some variables can only in some of the countries be satisfactory described by representative quantitative data and often only part of the relevant period is covered ${ }^{1}$. It has therefore not been possible to collect a

\footnotetext{
${ }^{1}$ The frequency of employee ownership in the different countries are base on different types of data - total frequency numbers for some specific ownership types like worker cooperatives, representative survey data, cases for smaller groups of companies. There are used varying definitions of employee ownership (majority, largest ownership share,
} 
consistent dataset to make a stringent quantitative analysis. Instead the article gives a qualitative analysis where the separate countries are treated as cases and the main trends are uncovered. The analysis gives an overview over the core variables and their possible impact pointing to the conclusion with answers on the given research questions.

\section{Different types of employee financial participation}

There can be identified three core owner rights: the right to control, the right to the surplus and the right to the company wealth - net-worth. Shareholders typically get a share in all three rights. Employee representation in company boards - like in Scandianvia or like the German codetermination - is an example where employees get a share of the control rights without any share of the financial rights. In these countries the company law gives the employees the right to a certain number of seats in the boards of joint stock companies of a certain size. In some countries different systems of profit-sharing gives the employees certain rights to part of the surplus without control rights or rights to get a capital gain through share-ownership. Table 1 gives an overview over some of the main forms of employee participation in the different owner rights.

Table 1. Different forms of employee participation in different owner rights

\begin{tabular}{|l|c|c|c|}
\hline Type right to: & Control & Surplus & Wealth \\
\hline controlling employee ownership & + & + & + \\
\hline ESOP Emploee Ownership Stock Plans & often limited & + & + \\
\hline minority employee ownership & limited & + & + \\
\hline worker cooperatives & + & + & limited \\
\hline employee representation in company board & minority & $\mathbf{0}$ & $\mathbf{0}$ \\
\hline profit sharing & $\mathbf{0}$ & + & $\mathbf{0}$ \\
\hline
\end{tabular}

Some countries have for many years had special legislation promoting different types of employee ownership through tax benefits, direct subsidies or other advantages (Bartlett \& Uvalic, 1986), Uvalic, 1991; Uvalic, 2006). In the US ESOPs (Employee Stock Ownership Plans) the shares are owned by an employee fund, which in the start often are leveraged by loans with collateral in the company. The shares are then gradually transferred to the employees often in the form of profitsharing. The system has been supported by tax-advantages and covers now 8.8 millions employees or around $6 \%$ of the US labour force. However, in most cases the voting rights are not executed by the employees, but by a board of trustees for the employee fund without direct control from the em- 
ployees. Still, there are several thousand firms where the employees themselves execute the control rights (Rosen et al, 2005).

Worker cooperatives are often based on the classical cooperative principles of one vote per member and open membership. Only the employees can be members and they have one vote each at the general meeting. There is possibility of membership for new employees, and those leaving the company are in most cases obliged to sell their membership stakes. The value at sale is, however, often limited so the employees cannot realize possible capital gains. This type has been named: collective ownership (Mygind, 1987). This is quite similar to the Yugoslav model, often named social ownership. Here, the employees had the right to control and the right to the income flows, but they could not realize the accumulated capital when leaving the firm. The most widespread form of employee ownership in the later transition economies has been individual ownership, where the employees individually own shares which can be sold at the market.

\section{Conditions for the spread of employee ownership}

Which conditions promotes and which hamper the start and development of employee ownership? Most studies show that employee ownership leads to higher motivation and thus higher labour productivity (Kruse og Blasi 1997, Pérotin og Robinson 2003). However, employee owned companies have often problems of attracting sufficient capital and problems of creating an internal market for individual employee shares. Dow (2003) finds the basic differences in relation to capitalist owned firms in the following three problems: Employee owned firms have a commitment problem in relation to supply of external capital, a composition problem in relation to collective decision making in the group of employee owners, and a commodification problem of trade with employee shares in relation to entry and exit of employees. Promoting and hampering conditions for employee ownership are related to a broad set of factors: institutions, culture and technology. These conditions will in the following be presented on the society-, company- and individual levels. However, it must be emphasized that there is a close interaction between these three levels.

On the society level it is important how different institutions are developed in relation to the choice of the employees between being owners or being ordinary wage-earners without owner rights. Relevant institutions in this context are: labour market regulation, tax legislation, company law, access to finance for employee owned firms etc. There is an effect of substitution between the conditions 
on the labour market with good employment opportunities and a good safety net in case of unemployment and the incentive to establish employee owned firms to secure stable and good employment conditions. Strong unions and good wage-earner conditions may imply low incentives to become an employee owner. Employee representation in the company board and management styles with high participation of employees may have the same effect. If employees can participate anyway why bother about ownership? These conditions are probably an important explanation behind the limited occurrence of employee ownership in the Scandinavian countries. The high frequency of employee owned companies in Southern Europe and US is probably connected to higher uncertainty on the labour market, but another explanation is the institutions with favourable conditions for employee ownership. In Italy, Spain and France worker cooperatives are widespread. The ownership structure is clearly defined in the company law and there are different advances in relation to taxation and finance. In Scandinavia such supporting institutional rules are only found in specific sectors like for kinder-gardens in Sweden (Pestoff, 2000).

At the company level the decisive factors are: the collective decision making among the employees, the possibilities of getting external finance, and the importance of human capital. The problem of collective decision making among employees increases with the number of employees, with higher heterogeneity and conflicts in the group of employees, and with higher complexity. Dow (2003) compares this composition problem for the employee owned firm with the situation in the traditional external investor owned firm where the group of owners often is smaller and the investors have parallel interests. Hansmann (1996) emphasizes the problem of decision making in a heterogeneous group of employees. Therefore, the employee owned firm will tend to be relatively small and with a homogenous labour force. If there are conflicts between different groups of employees the ownership will be limited to a smaller group of core employees. This is often the case in knowledge based companies with high dependence on human capital. The knowledge is often specific to the company, so it loses value if the employee shifts to another company. This makes a mutual dependence between company and employee and may be a main driver for employee ownership. However, in a heterogeneous group of employees it will often only be the knowledge intensive employees who become owners.

Teamwork and employee participation is used by modern management to promote motivation and higher productivity. This may include participation in ownership in different forms as profit- 
sharing, minority employee shares or representation in different decision making bodies (Kaarsemaker and Poutsma, 2006). In this way some of the advantages with employee ownership is exploited without loss of the decisive control for the external investors. According to Dow (2003) it is, however, not possible to get the full effect of motivation without employee ownership. Even with elements of employee ownership there will in the external investor owned company continue to be a commitment problem. However, Scandinavian management with high employee participation may lower the pressure for employee ownership.

The problem of finance in companies with high capital intensity is a classical problem in the literature on employee owned firms (Vanek, 1971; Meade, 1972; Putterman, 1988). High capital input per employee means that the demanded capital becomes too high for most of the employees. At the same time there is a commitment problem in relation to external capital like minority shares or bank loans because there may be a conflict between the objectives of the employee owners and the levels of return for the external capital. This leads to the theoretical prediction that employee owned firms have quite low capital intensity. This corresponds to most empirical evidence with a few exceptions including the Mondragon cooperatives in the Basque country of Spain. These firms have full employee ownership with one vote per employee. They combine a high degree of individual ownership with quite capital intensive production. This has been possible because a strong bank makes up the core of the Mondragon Group. (Thomas og Logan, 1982; Whyte og Whyte, 1991).

On the individual level culture and socio-economic conditions play a decisive role. Are the employees motivated to take over the enterprise? Do they have the necessary capital and expertise to succeed? The desire for self-governance including the desire to participate in decision making at the workplace can be an important driver behind employee ownership. On the other hand may there be an important barrier if the employees are dominated by wage earner consciousness fully accepting that ownership and control belong to an external owner (Højrup, 1983). But the desire for participation is not enough. The employees must also have the necessary skills to participate in decisionmaking. They must be ready to offer time and effort to be active in the often demanding decision process. This explains why employee ownership is more widespread among highly educated and experienced employees. In knowledge based enterprises the highly educated employees have often better access to the necessary information for controlling and challenging management. 
The personal wealth of each employee is important when a high initial stake is necessary to acquire ownership. Wealthy employees can finance the capital stake without concentrating a big part of their fortune in the same company in which they at the same time have invested their human capital. This concentration of risk can be seen in combination with the employees' culture and their attitude to risk taking. If employees both risk a substantial part of their personal wealth and their jobs they put all their eggs in the same basket (Meade, 1972; Putterman, 1993). The risk of losing the specific human capital related to the job can also be an important reason for employee ownership (Blair, 1995). The costs of losing the job depend on the mobility of the employees and their alternative employment possibilities. Thus, the desire for employee ownership will increase with increasing unemployment. On the other hand high unemployment benefits and a developed social safety net will decrease the pressure for defensive employee takeovers to secure employment.

In this way there is a close connection between the conditions on the different levels: The individual choice between ownership and wage-earner position depend on both individual desires as well as the conditions at the company- and society levels.

\section{Special conditions for employee ownership during the transition in Eastern Europe}

The earlier section showed how specific conditions at the society-, company- and individual levels give certain possibilities and barriers for start and development of employee ownership. This section goes deeper into the specific conditions in the transition process in Eastern Europe and impact on the spread of employee owned companies. The analysis is still on the theoretical level and results in some predictions for the spread of employee ownership in the different countries.

On the level of society the transition is mainly about changing institutions. The political institutions were changed with the introduction of democratic constitutions. The economic institutions were changed through the development of different market institutions over a longer period. This included new rules of the game for enterprises, first of all a change from state to private ownership. This privatization had major influence on the development of employee ownership. Also the new institutions related to corporate governance like company law, tax legislation and the development of the financial sector had strong impact on the spread of employee ownership (Mygind, 2001). 
The shift from plan to market in Eastern Europe marked the start of the most comprehensive privatization in history. Privatization made the foundation for a new distribution of wealth and power. Therefore, it was an important issue in the political process and shifting political power structures implied strong shifts in the political process and further shifts in the models of privatization in many countries through different stages of transition. According to the official ideology of the command economy the enterprises were owned and controlled by the working class, but administered by the communist party. Giving the companies back to the employees was in fact to give them back to the legitimate owners. Privatization was transition from central to decentral ownership without the state as intermediary. However, in the political debate considerations for economic efficiency, revenue for the state, development of the stock exchange etc. were used as arguments for other models.

The political process was very complex so it is difficult to uncover the decisive factors for support or lacking support for employee ownership. High political strength of the workers may support privatization models leading to employee takeovers. Employees could get the first right to purchase the company and may be able to pay a relatively low price. This could be combined with advantageous loans. Such models could be combined with voucher privatizations where the whole population got privatization vouchers as it was the case in Lithuania.

The transition countries went through a comprehensive development of new institutions in nearly all fields. Some of these changes like price- and trade liberalization were relatively fast, while the establish of corporate governance institutions in relation to company law, shareholders rights, the development of the judiciary for enforcement as well as the development of the financial system was relatively slow (EBRD, 2007). Therefore, the protection of external owners, especially minority owners, was weak in the first stages. These conditions favoured insider ownership both in the form of manager- and employee owned enterprises. In parallel with the development of institutions and development of banking and capital markets there was an improvement in the conditions for external ownership (Mygind, 2001). In countries such as Estonia and Hungary where this development was fastest you may therefore expect a faster change away from employee ownership.

The theoretical predictions on the company level points as already mentioned in the direction of higher frequency of employee ownership in firms, which are relatively small, with homogenous labour force, with knowledge intensive production, and with low capital inputs per employee. This 
means that employee owned firms especially is expected to be found in IT, consulting, professional firms etc. This means also that a higher frequency is expected in the countries with the highest GDP per capita like Slovenia, Czech Republic and Hungary. Advanced management methods may imply, that especially multinational investors in Eastern Europe introduce minority-employee shares and other kinds of financial participation as incentive enhancing schemes for their employees.

At the individual level it is a question whether the long period of command economy with party dictatorship has created special conditions in relation to:

- Working culture with specific attitudes of the employees and specific employee skills in relation to ownership and governance of their own enterprises

- income and wealth

- risk aversion

- $\quad$ special conditions for mobility including alternative job opportunities

The official ideology in the communist countries emphasized the development of the communist man with collective attitudes and with active participation both at the work place and in the society in general. In practice there was a gap between the official ideology and the actual practice with dictatorship enacted by a narrow elite, a hierarchical society with paternalistic management in the enterprises - that is bottom down management with minor participation of the employees.

However, there was strong variation between the different countries and through time there were some attempts to develop certain forms of labour participation. Most of these attempts like in Hungary 1956 and Czechoslovakia 1968 were stopped by Soviet intervention even before they really developed. However, from the 1960es a self-management system with market oriented economy, was developed in Yugoslavia. This system included a high degree of employee participation and ownership. However, there were large differences in the actual implementation in the quite diversified country. Employee participation functioned much better in the developed parts of Yugoslavia with Slovenia in front, while the poor regions in the south like Kosovo and Macedonia continued to be governed by the communist party in the traditional way (Neersø, 1982).

Hungarian reforms introduced in the 1960es the "second economy" with some decentralized market elements. Also Poland had stronger market orientation, but not before the 1980es. In the end of the 1980es important changes took place in the Soviet Union, especially in the Baltic countries. This 
was part of the early transition, but came so late that it did not implement a culture for employee participation. These trends indicate that especially in the developed parts of Yugoslavia there were developed a culture of employee participation which later could support a development of employee ownership. There were also some elements of this in Poland and Hungary, while the remaining countries were to higher degree dominated by traditional paternalistic management with quite passive employees.

Figure 1 The development of GDP 1989=10, based on EBRD (2006)

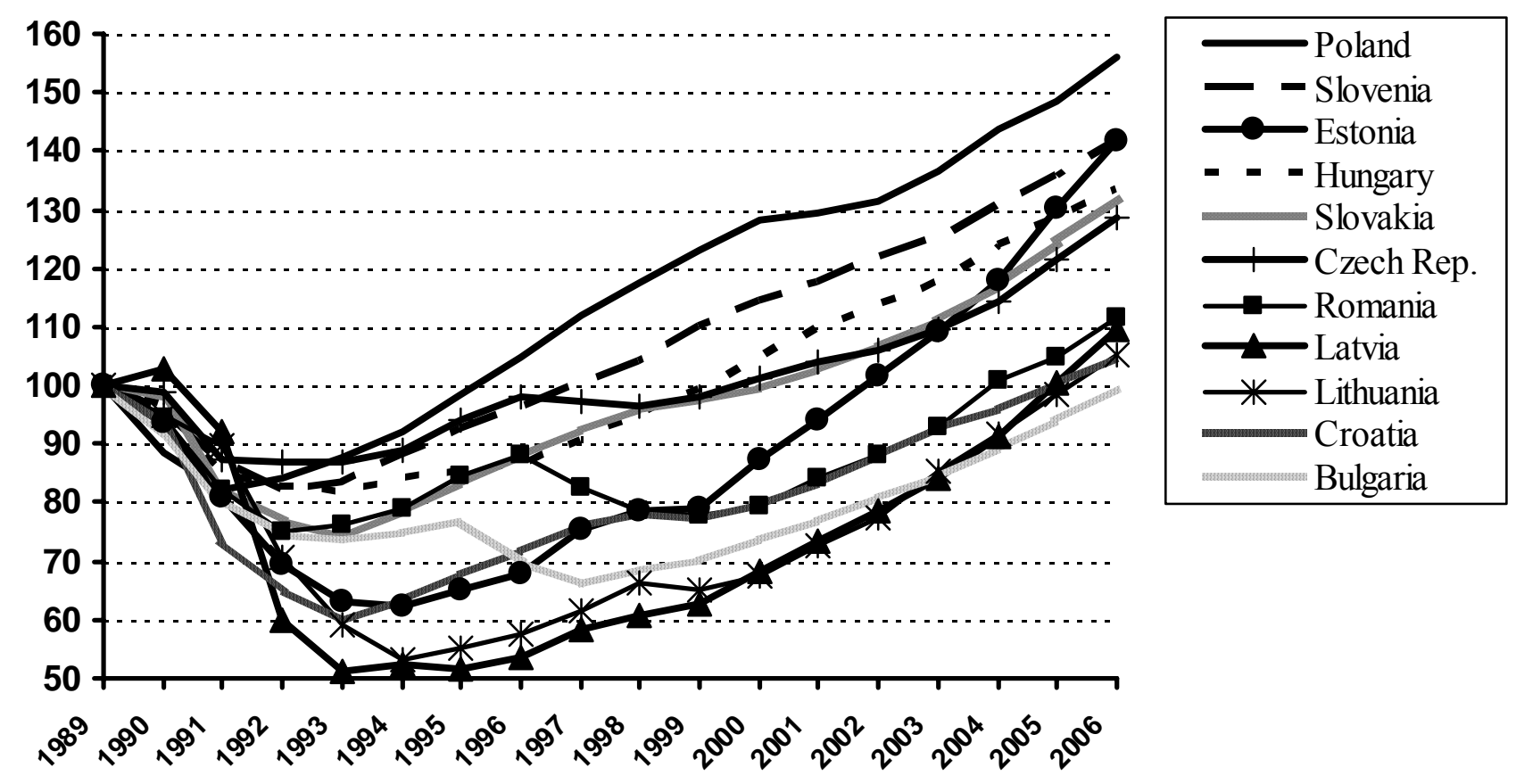

Low income and wealth in relation to the demands for capital input per employee can as mentioned earlier be important barriers for employee ownership if there are no special finance opportunities to solve this problem. Here was an important barrier for the spread of employee ownership in Eastern Europe because there was a drastic fall in income for the majority of the population in the first years of transition. Production followed a J-curve with a steep fall in the first half of the 1990es, and then after the turnaround there were quite high growth rates in the later years, see figure 1.

The fall was especially strong for the countries belonging to the former Soviet Union. The reason for the steep fall was that the new market demanded a completely new production structure. The old production lines fit for the directives of the planning bureaucracy did not fit to the market economy where market based costs and customers demand determined production. The production lines 
could be closed down rather fast, but it took years to build up a new production structure with new products, new production methods, new organizational structures etc. (Mygind, 1994). All over Eastern Europe there were for several years a steep fall in production and real wages, and employees had no surplus for buying their own enterprises although the price was low. There were big differences between the countries. The fall in production and income was steepest in the Baltic countries, while Poland experienced an earlier turnaround. Slovenia had a relatively small fall, and here the fall was not because of a fast change from plan to market. The Slovenian economy was because of the old Yugoslav self-management system already market oriented at the start of the 1990es, but because of the war in the other parts of former Yugoslavia Slovenia lost much of its old markets and had to make further restructuring of production to increase trade with EU. Still, the Slovenian income level was and is clearly the highest in Eastern Europe, see figure 2. Then follow the Czech Republic and Hungary, while Bulgaria and Romania lie at the bottom. This is also the case for the Baltic countries, but they are now in a process of very fast catching up. Based on this development there can be expected more employee ownership in Slovenia and The Czech Republic, while low income levels can explain why employees who got cheap shares in early transition quite quickly sold these shares again. This tendency is expected to be strongest in countries like Romania, Bulgaria, Latvia and Lithuania.

Figure 2 Average yearly wage in Euro (Eurostat)

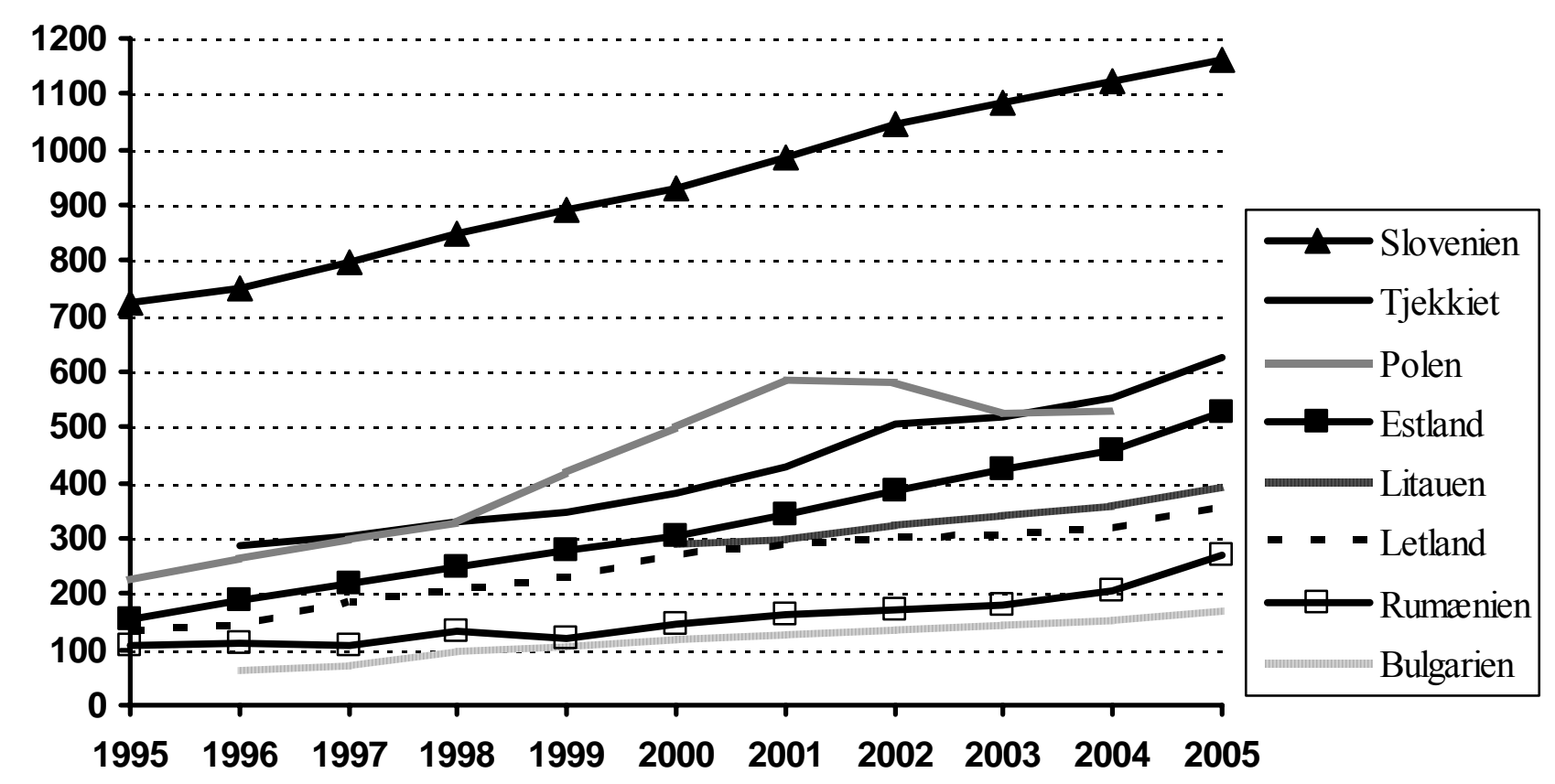


Risk aversion can as mentioned be an important barrier for employee ownership. There is no evidence that East Europeans should have a specific low risk aversion (Shiller m.fl. 1991), but the new markets developing since 1989 had much more volatility and uncertainty than the markets in Western Europe. This uncertainty can be expected to make an important barrier especially in the less developed East European countries.

There are also elements turning in the opposite direction. In the command economy many large enterprises were located in relatively small cities. They were the sole employer for the local area. The housing market was developed quite late in the transition process, and restructuring of production gave bottlenecks for relocation and training of the labour-force to the new market oriented sectors. There were relatively low labour mobility and in most countries there was high unemployment especially in the first years and especially in the peripheral areas. This could be an important reason for defensive employee takeovers where the employees seek to save their workplace through employee ownership. This can be expected in countries which have experienced high unemployment like Bulgaria, Croatia, Latvia, Lithuania, Poland, Romania, and Slovakia, see table 2.

Table 2 Unemployment rates - labour force survey, end year (Eurostat)

\begin{tabular}{|l|r|r|r|r|r|r|r|r|r|r|r|}
\hline & $\mathbf{1 9 9 6}$ & $\mathbf{1 9 9 7}$ & $\mathbf{1 9 9 8}$ & $\mathbf{1 9 9 9}$ & $\mathbf{2 0 0 0}$ & $\mathbf{2 0 0 1}$ & $\mathbf{2 0 0 2}$ & $\mathbf{2 0 0 3}$ & $\mathbf{2 0 0 4}$ & $\mathbf{2 0 0 5}$ & $\mathbf{2 0 0 6}$ \\
\hline Bulgaria & & & & & 16,4 & 19,5 & 18,1 & 13,7 & 12 & 10,1 & 8,9 \\
\hline Czech & & & 6,4 & 8,6 & 8,7 & 8,0 & 7,3 & 7,8 & 8,3 & 7,9 & 7,2 \\
\hline Estonia & & 9,6 & 9,2 & 11,3 & 12,8 & 12,4 & 10,3 & 10,0 & 9,7 & 7,9 & 5,6 \\
\hline Latvia & & & 14,3 & 14,0 & 13,7 & 12,9 & 12,2 & 10,5 & 10,4 & 8,9 & 6,9 \\
\hline Lithuania & & & 13,2 & 13,7 & 16,4 & 16,5 & 13,5 & 12,4 & 11,4 & 8,3 & 5,9 \\
\hline Hungary & 9,6 & 9,0 & 8,4 & 6,9 & 6,4 & 5,7 & 5,8 & 5,9 & 6,1 & 7,2 & 7,5 \\
\hline Poland & & 10,9 & 10,2 & 13,4 & 16,1 & 18,2 & 19,9 & 19,6 & 19,0 & 17,7 & 14,0 \\
\hline Romania & & 5,3 & 5,4 & 6,6 & 7,2 & 6,6 & 8,4 & 7,0 & 8,1 & 7,2 & 7,3 \\
\hline Slovenia & 6,9 & 6,9 & 7,4 & 7,3 & 6,7 & 6,2 & 6,3 & 6,7 & 6,3 & 6,5 & 6,0 \\
\hline Slovakia & & & 12,6 & 16,4 & 18,8 & 19,3 & 18,7 & 17,6 & 18,2 & 16,3 & 13,3 \\
\hline Croatia & & & & & & & 14,7 & 14,1 & 13,6 & 12,6 & \\
\hline
\end{tabular}

\section{Fast change in ownership after privatization}

The privatization resulted in a high frequency of employee ownership in some countries with special advantages for this owner type. Without this support the employees neither had the economic possibilities nor enough motivation for takeovers. Here is probably an important explanation why employee ownership only survived for a quite short period in most countries. The steep fall in incomes, the high uncertainty and lack of financing, were important reasons behind the fast sell off of 
employee shares. Defensive job protection could postpone the process, but this counteracting factor become in general weaker over the transition period. Therefore, it can be expected that the number of employee owned companies fall steeply in those countries where it started up at a high level because of advantages in privatization. However, the speed of the fall and the time for stabilization and perhaps later growth depend on how advanced the country is in the transition process and the economic level of development.

There have been done much research on the economic efficiency of employee owner enterprises compared with similar externally owned enterprises. Some of the recent analyses cover the specific conditions in Eastern Europe. In a review of the of empirical studies in this area in Eastern Europe, Jones (2004) finds quite contradictory results. Only few results indicate that employee owned enterprises have lower efficiency. Most studies show relatively high factor productivity for employee owned firms, but combined with relatively low investment level. They have low inputs of external capital including bank loans, and this leads to lower investments. Factor productivity in employee owned firms is on the level of the best performing group, foreign owned companies, which are based on higher capital intensity and higher levels of investments (Jones \& Mygind, 2002). Thus, it cannot be concluded that the fall in the number of employee owned enterprises is caused by low efficiency. However, the lack of capital can be an important reason for the change toward external ownership.

\section{Overview over the development of employee ownership in eleven East European countries}

Table 3 gives an overview over privatization and the development of employee ownership and the frequency in the ten new East European member-states of EU plus the candidate country Croatia.

Bulgaria. There were some minor attempt for increasing employee participation during the 1980es, but the reforms did not take off before after the political changes in 1989. One of the three large unions were actively promoting employee ownership, but the unions were weak and lost further influence during the transition process (Ivanova \& Keremidchiev, 2006). The voucher privatization during 1996-1998 covered 1040 large enterprises. 10\% of the shares in each company were freely distributed to the employees. Furthermore, there could be established special managementemployee-companies if at least $20-30 \%$ of the employees participated. This group could buy the company and get certain tax advantages corresponding to a $36 \%$ reduction of the price. About half 
of around 5000 applicable medium sized companies were privatized in this way. The process was mostly initiated by management who often later took over the majority of shares. In a study of 20 such firms Minchev (2004) shows, that 17 are now under full control of management. Only in 2 companies the employees have still control while one company is externally owned.

Table 3 Overview over the development of employee ownership (EO) Eastern Europe

\begin{tabular}{|c|c|c|}
\hline & Privatization (P) related to employee ownership & Spread and development of EO \\
\hline Bulgaria & $\begin{array}{l}199210 \% \text { of shares to employees in voucher priv. } \\
20 \% \text { of shares to employees at half price } \\
1996-2000 \text { tax advantages for employee ownership }\end{array}$ & $\begin{array}{l}1040 \text { firms } 6.5 \% \text { shares to empl. } \\
\text { ownerhip in earlier EO by } 2006 \text { : } \\
5 \% \text { extern, } 85 \% \text { manager, } 10 \% \text { EO }\end{array}$ \\
\hline Croatia & $\begin{array}{l}1991 \text { Markovic' Transformation law for Yugoslavia } \\
\text { Part of social owned firms to employees at low price. } \\
\text { After war, } 1996 \text { no support to EO, still some ESOPs }\end{array}$ & $\begin{array}{l}2586 \text { EO in early stage, SMEs } \\
199520 \% \text { of shares owned by } \\
\text { employees, } 1998 \text { fall to } 12 \% \text {. }\end{array}$ \\
\hline Czech Rep & $\begin{array}{l}\text { Voucher privatization without advantages for em- } \\
\text { ployees, barriers for EO in privatization } \\
\text { By law: employee representation in company boards }\end{array}$ & $\begin{array}{l}\text { newspapers EO, now external } \\
\text { Now: minority EO in banks and } \\
\text { other foreign owned companies }\end{array}$ \\
\hline Estonia & $\begin{array}{l}\text { EO 1989-91 Soviet, new cooperatives and leasing, } \\
\text { EO favoured in small privatization until } 1992 \\
\text { No advantages for employees in large privatization }\end{array}$ & $\begin{array}{l}\text { Most small firms EO until } 1992 . \\
\text { Only EO in a few large firms. } \\
\text { Most EO taken over by managers }\end{array}$ \\
\hline Hur & $\begin{array}{l}\text { Early privatization, low price of max } 15 \% \text { of shares } \\
\text { ESOP-model for minimum } 40 \% \text { of the employees } \\
\text { ESOP-loans, shares to employees with repayment }\end{array}$ & $\begin{array}{l}540 \text { firms, } 15 \% \text { employee shares } \\
287 \text { ESOPs } 1992-9547 \% \text { with } \\
\text { EO majority, } 2005 \text { still } 151 \text { ESOP }\end{array}$ \\
\hline La & $\begin{array}{l}\text { EO 1987-91 Soviet: new cooperatives and leasing } \\
\text { EO favorized in privatization of small firms to } 1994 \\
\text { EO in leasing with option to buy, } 234 \text { medium firms } \\
\text { No advantages for employees in large privatization }\end{array}$ & $\begin{array}{l}\text { Most small firms EO until } 1994 \\
\text { SME many leased by employees } \\
\text { Only few large firms. } \\
\text { Most EO taken over by managers }\end{array}$ \\
\hline Lithuania & $\begin{array}{l}\text { EO 1987-91 Soviet: new cooperatives and leasing } \\
\text { Large voucher privatization 1992-95, favorizing EO } \\
\text { up to } 50 \% \text { of shares,later privatization no advantages }\end{array}$ & $\begin{array}{l}1 / 3 \text { of privatized firms got EO } \\
\text { Also larger capital intensive firms } \\
\text { Most EO taken over by managers }\end{array}$ \\
\hline Poland & $\begin{array}{l}\text { Privatization by liquidation, many medium firms } \\
\text { Main model: EO leasing/takeover with advantages } \\
\text { Voucher privatization, } 15 \% \text { free to employees } \\
\text { By law: employee representation in company boards }\end{array}$ & $\begin{array}{l}1990-95 \text { EO in } 50 \% \text { of SME-priv. } \\
\text { Fall in EO \& share to employees } \\
1999 \text { still } 1 / 3 \text { majority EO } \\
\text { empl.11\% of shares in large firms }\end{array}$ \\
\hline Romania & $\begin{array}{l}\text { ESOPs if minimum } 30 \% \text { of employees are owners, } \\
\text { advantages on price, loan, interest } \\
\text { certain possibilities for EO in voucher privatization }\end{array}$ & $\begin{array}{l}\text { ESOPs } 1 / 3 \text { of industry, } 2632 \text { firms } \\
\text { EO: } 30 \% \text { measured by employees } \\
\text { EO: } 10 \% \text { measured by capital }\end{array}$ \\
\hline Slovakia & $\begin{array}{l}\text { First voucher privatization without EO advantages. } \\
\text { 1995-98 formal EO advantages, but not implemented } \\
\text { Some management led EO takeovers } \\
\text { By law: employee representation in company boards }\end{array}$ & $\begin{array}{l}\text { Few EO cases, management led } \\
\text { Often minority employee shares } \\
\text { In foreign owned companies }\end{array}$ \\
\hline Slovenia & $\begin{array}{l}\text { Large firms: } 40 \% \text { funds, } 20 \% \text { employees }+40 \% * \\
\text { *bought by employees (internal priv.) or by outsiders } \\
\text { By law: employee representation in company boards }\end{array}$ & $\begin{array}{l}90 \% \text { firms: internal privatization } \\
\text { Most in small and labour inten- } \\
\text { sive enterprises }\end{array}$ \\
\hline
\end{tabular}


Croatia was after Slovenia the most developed part of the former Yugoslavia. There was a strong tradition for employee participation in control and surplus of the enterprises. But in contrast to Slovenia Croatia was hit hard by the civil war and several years of nationalist government under general Tudjman was hampered by corruption and nepotism. The Marcovic laws from the period shortly before the dissolution in 1989-90 planned a privatization with continuing elements of the social ownership for employees. This legislation were partly included in the first Croatian law on “transformation of enterprises under social ownership” from 1991 (Brnabić, Goić \& Završak, 2006). The employees got a reduction in price based on tenure from $20-70 \%$ for purchase of individual employee share, though max $50 \%$ of the shares could be sold in this way. The remaining shares were transferred to a pension fund and to a fund for later privatization. Because of the war in the first half of the 1990es the economy was in recession. In many firms the possibilities for employee takeovers were not exploited. Many firms went bankrupt and more than half of the employee share purchase contracts were not fulfilled. Therefore, the early employee takeovers got only limited impact. In the new privatization law from 1996 there was not made specific opportunities for employee takeovers. The goal was instead to attract foreign investors for rebuilding and restructuring the economy. It is estimated that $20 \%$ of the nominal value was taken over by employees in 1995, but sale of employee shares resulted in a fall to $12 \%$ by 1998 (Jelušić \& Perić, 1999). However, the earlier experience of employee ownership has later been reflected in a certain development of ESOP models in some of the larger enterprises. ESOPs give an opportunity for combining individual share ownership with collective control for the group of employees through the ESOP organization. A survey from 2003 of 552 firms with ESOP systems showed that 66 of them had majority control and worth noting, this was especially widespread in the largest firm (Brnabić, Goić \& Završak, 2006).

Estonia. The reform oriented groups got considerable power after the 1990 elections in the different Soviet republics. The first reforms were designed in this early period with strong emphasis on employee ownership. This concerned the socalled "peoples enterprises" where the group of employees were supposed to take over control. However, only 6 enterprises went through this type of privatization (Terk, 2000). The early Soviet reforms from 1987 had stronger effects through the start up of a high number of "new cooperatives" in restaurants, trade and small manufacturing. They were formally collectively owned by the employees, but in practice they were the first start-ups of management owned enterprises. At the same time it was made possible for the group of employees to take 
over their enterprise through leasing and this possibility was exploited in quite many enterprises in the Baltic countries (Frydman m.fl., 1993). Estonian legislation from 1991 gave managers the possibility to lease the enterprise without participation from the rest of the employees. The privatization of small firms gave in the first years substantial advantages to the employees, but already from 1992 these advantages were diminished and in the following legislation for large privatization of medium and large enterprises there were no advantages for the employees. This remarkable shift in privatization is closely connected to changes in politics in the early transition (Mygind, 1994) see below.

A survey of around 500 firms on their ownership development from privatization to 2005 show, that employee majority especially were found in small enterprises with low capital per employee (Mygind 2000). This fits well with the theoretical predictions. The empirical analyses of the efficiency of employee owned firms show that they are not performing worse than other domestic firms. Still there is a significant fall in the number of this type of enterprises. Both in-depth casestudies as well as quantitative analyses show that there can be identified specific ownership cycles for the Estonian firms. A quite high number of firms started up as employee owned after privatization. In the next stage they were taken over by management and then in a later stage they were often taken over by concentrated external investors, often foreign (Jones og Mygind, 2006).

Hungary had quite volatile relations to employee participation in the period since the Second World War. During the revolt in 1956 there were plans for strengthening workers councils in the companies. However, the revolt was crushed by Soviet tanks. After some years of reaction came the Hungarian reforms with the new economic mechanism in 1968 with market orientation, different forms of profit sharing and decentralization. After the democratization in 1989 and the start of a deeper transition to market economy employee ownership came again on the political agenda. The unions were active both in the political discussions and in relation to local initiatives for employee takeovers. In the early privatization there were certain advantages for employee purchase of up to $15 \%$ of the share capital in the form of lower price and loans with favourable repayment schemes and low interest rate. This model was used in 540 enterprises (Boda, Neumann \& Vig 2006). In 1992 a law on ESOPs were passed. These Employee Stock Option Plans were especially used in connection to privatizations, but could also be used for employee takeovers of private companies. There were certain tax-advantages connected to the ESOPs. 287 ESOP enterprises with 80.000 employees were established 1992-94 before the advantages were abolished in 1995. In the start almost 
all were majority takeovers, but later some ESOPs got only minority share holdings. A status from 1995 shows that the ESOP fund had majority in $47 \%$ of the cases. In relation to the total number of enterprises ESOPs never made up a substantial part. Less than $1 \%$ of the total Hungarian company assets were covered by ESOP structures by 1998. Still, the number was not falling as steeply as in the Baltic countries. By 2005 there were 151 ESOP enterprises left. (Boda, Neumann og Vig 2006).

Latvia has in relation to employee ownership followed a line quite similar to the development in Estonia. The first employee owned firms started under the Soviet legislation for new cooperatives and leasing. The early Latvian legislation gave substantial advantages for insider takeovers in the privatization of small enterprises within trade, services and small manufacturing. However, as part of the nationalistic oriented change of politics these advantages were abolished already in the start of 1992, but in practice the advantages of insiders, often dominated by management, continued in the following years (Frydman m.fl. 1993). The employees had also the opportunity to take over medium sized companies through the Latvian version of privatization by leasing with option to buy. This model covered around 200 firms. According to a survey of 915 firms about $30 \%$ of them had majority employee ownership in 1995 with strongest weight within small and medium sized firms. This frequency fell to around 16\% in 1999 (Jones \& Mygind, 2006). Except from a few early experiments the large privatization in Latvia was based on direct sale with good opportunities for capital strong investors, especially foreigners. In this way Latvia followed Estonia with a few years delay.

Lithuania went through a very interesting privatization process seen in relation to employee ownership. Already before independence in 1991 there were developed plans for employee ownership and in contrast to Estonia and Latvia these models were further developed in the first years of transition, so not only small, but also medium and large enterprises got a substantial element of employee ownership in the early important stage of privatization. This "initial privatization" (LIPSP) were approved already in February 1991, before full independence. The employees got the possibility to buy $10 \%$ of the shares at a preferential price in the first round. This percentage was increased to $30 \%$ in 1992 and to $50 \%$ early in 1993 . LIPSP was to a high degree based on privatization vouchers distributed to the whole population and included the majority of enterprises. However, the state kept dominating shares in the largest and strategic important enterprises. These state shares were privatized in the years following the end of the LIPSP-program in 1995. This year marked the 
end of the advantages for employees in the privatization. A survey of 405 firms showed that the employees got majority in more than one third of the privatized enterprises. However, the analysis shows that the number of employee owned firms fell steeply so only $12 \%$ of the privatized firms were employee owned in the start of 2000. Most had changed to management ownership and some further to concentrated external ownership (Jones \& Mygind, 2006).

Poland is characterized by quite organized labour and the union, Solidarity, played a decisive role for the political transition of Poland. Already in the start of the 1980es the pressure from Solidarity had resulted in more employee participation in the governance of the enterprises. This was decisive when privatization started in the early 1990es. The workers in the enterprises had an important role for recognition of the privatization plans and therefore they got considerable confessions often in the form of some degree of employee ownership (Lowitzsch \& Woodward, 2006). One of the results was a special model for employee-leasing, which became widespread especially in small and medium sized enterprises with less than 500 employees. A newly established company owned by at least $50 \%$ of the employees leased the enterprise for a period of maximum 15 years. The model for financing included some subsidies. While other forms of Polish privatization developed quite slowly at this point, the employee leasing model developed fast and made up around half of the privatization up to 1995 (Lowitzsch \& Woodward, 2006). The large privatization were implemented quite slowly often as sale to a concentrated external owner. An exception was the mass-privatizaton program including 412 large companies. This was a voucher privatization through 15 national investment funds. The population got ownership to these funds through vouchers. Up to $15 \%$ of the shares in the companies were given to the employees. The value of these shares could not exceed 1.5 times the average wage and could not be sold before after 3 years.

In the period after privatization there was like in the Baltic countries a process with concentration of ownership especially in the hands of management. For 1990-1998 the starting point in most employee leased enterprises was a quite equal distribution of ownership. However, the share owned by employees fell from an average of $58.7 \%$ just after privatization to $31.5 \%$ in 1999 , when still $1 / 3$ of these firms were majority owned by employees. In this way the fall of employee ownership was somewhat slower than in the Baltic countries. In the large firms the employees owned on average $11.4 \%$ of the shares in 2000 (Kozarzewski, 2002). Analyses of the profitability of the employee 
owned firms showed in general the same level as in other firms (Jarosz, 2000) confirming the result from the Baltics that the fall in employee ownership was not caused by low efficiency.

Romania had no tradition for employee participation before the political transition in the end of 1989. As part of the voucher privatization it was made possible for the employees to get up to $30 \%$ of the shares. Employees could use their voucher for privatizing their own companies even if they were not included in the list of firms to be privatized through vouchers, but this type of privatization included only quite few employee takeovers. In connection to direct sale to an external investor the employees could buy shares with 10\% discount (Albu \& Bormann, 2006). The most prevalent form was the special ESOP firms introduced already in January 1992. From the start the model was directed towards small firms, but also medium sized and even a few large companies used this form or privatization. A majority stake was sold to an ESOP organization, which should cover at least $30 \%$ of the employees. This organization administered the shares for their members including also the voting rights. There were some subsidies for the loans to the ESOP organization. The ESOP system resulted in many employee takeovers culminating in the years 1994-97. At the end of 1998 over $1 / 3$ of the manufacturing firms were taken over by an ESOP with average employee proportion of the shares of $65 \%$. In 2000 the total number were

2632. ESOPs made up $30 \%$ of ownership of the total number of firms measured in proportion to their employment and 10\% measured with capital as the weight. Thus, they were in this way less capital intensive than the average (World Bank, 2004; Earle \& Telegdy, 2002).

Czech and Slovakia implemented already before the split in 1993 the first round of voucher privatization. Since the "Prague Spring" of 1968 Czechoslovakia had been governed by a highly centralized command economy without employee participation. In the debate about privatization there was also a discussion on employee ownership. But the Social Democrats supporting employee ownership had a quite weak position at this time (Kotrba, 1997) and the final model followed to a high degree the ideas of Minister of Finance, Vaclav Klaus. No advantages were given to the employees. They had formally the possibility for buying shares at the nominal supply price, but this price was in general higher than the final price. There were thus no employee takeovers in this privatization. After the split the Czech Republic implemented another round.

In Slovakia the winner of the election, Meciar, passed a law to support employee ownership, but it was never implemented. Instead privatization were done ad hoc to the advantage of Meciar's sup- 
porter, often as management controlled insider takeovers, where management got the majority, but where an important part of the employees also participated (Goecken, Lizal \& Klein, 2006). The later stages of privatization both in the Czech Republic and in Slovakia included the remaining state shares in the banks, telecomm, energy etc. which were privatized as direct sale to a concentrated external investor, often foreign. In summary, for both countries employee ownership was not promoted as it was the case in most other East European countries. There were a few examples of employee ownership in the newspaper industry, but after some years they were taken over by foreign investors. In the later years there have been distributed minority shares to employee owners especially in foreign owned companies (Heidenhain, Lizal \& Vychodil, 2006). As a sort of substitute Czech Republic and Slovakia has implemented legally obligatory employee representation in the boards of large shareholding companies.

Slovenia had since the 1960 es a developed system with collective or social employee ownership where the employees had the right to control and the right to surplus, but not the right to sell their share and get a capital gain. The system was rather successful and made the base for Slovenia's high competitiveness and market orientation. The country was only marginally involved in the Yugoslav civil war, but it lost the most important market. Employee ownership played a big role in Slovenian politics especially in connection with the privatization, but also in relation to the discussion on the development of employee participation in private companies. The Markovic laws never played an important role in Slovenia. The main privatization was implemented according to the law on ownership transformation from 1992. This law supported a distribution of ownership where different funds got $40 \%$ of the share capital $(10 \%$ to the pension fund, $10 \%$ to the compensation fund for earlier owners and $20 \%$ to the development fund for later sale to privatization-investments funds). Up to $20 \%$ went directly to the employees in exchange for vouchers. These employee shares were bonded for 2 years, but shareholder agreements could expand the bonding period. The remaining $40 \%$ could either go to internal privatization to the employees or to external privatization. The employees could buy these shares either by cash, through saved wages, or saved surplus from the Markovic period. Internal privatization became the most used form, but was not possible if the needed capital per employee was very high. $90 \%$ of the companies chose the internal privatization. In an overview over 1310 companies from 1999 the Privatization Agency found the following distribution of employee ownership: 
$11.5 \%$ of firms with $44.5 \%$ of capital and $14.7 \%$ of employees had $0-20 \%$ employee ownership. $27.3 \%$ of firms with $32.5 \%$ of capital and $39.7 \%$ of employees had $20-50 \%$ employee ownership. $51.3 \%$ of firms with $22.9 \%$ of capital and $45.7 \%$ of employment had $50-100 \%$ employee ownership. (Gregoric \& Ivanjko, 2006). Thus, there was widespread employee ownership though with dominance of relatively small and labour-intensive enterprises. This corresponds to a high degree with the theoretical predictions. From 1997 the employees could make special Workers' Associations for collective administration of employee shares. These associations got, however, only limited importance. Since privatization there has been a fall in the share of employee ownership from around $35 \%$ to $25 \%$ (Simoneti et. al. 2004), but in comparison to the development in other countries employee ownership was quite stable, and management takeovers were quite rare. In Slovenia it is, especially the group with concentrated external ownership which has increased (Mygind et al 2006). The empirical analyses of the effect of employee ownership on economic performance show, that they are more dependent on internal financing of the investments (Prašnikar \& Svejnar, 1998). At the same time employee ownership promotes the international competitiveness of the firm (Prašnikar \& Gregoric, 2002). Already in the constitution it is stated that the employees participate in the governance of the enterprises, and this was put into legislation in 1993. It says that employees shall have $1 / 3$ of the seats in the board and in companies with more than 500 employees also a representative in the management board.

\section{Other types of employee participation}

Workers cooperatives where in principle all employees are members with one vote each have only played a limited role in Eastern Europe. Like in Western Europe the cooperative movement had some influence in some countries in Eastern Europe together with the rise of the labour movement back in the start of the $20^{\text {th }}$ century. However, it was the consumer cooperation which became really strong in sectors like banking, housing and retail trade. Workers cooperatives were quite rare. In the command economies the cooperatives were integrated into the centralized planning and though they continued to exist in many countries the cooperative democracy was not implemented. At the start of transition some legislation supported the revival of the cooperatives, but without any significant results. Most important were the already mentioned new cooperatives which started the privatization in the Soviet Union already from 1987. They were among the first market oriented firms and were especially widespread in the Baltic countries, but nearly all these companies have later shifted legal form and have been taken over by management. 
Profitsharing has low incidence in Eastern Europe and this is also the case with minority employee shares used as an advanced tool for motivating the employees. Other bonus systems without direct relation to the profitability of the company are more widespread, and most of such incentive schemes cover only middle- and top-management. In most countries there are special employee shares, but they are most often not connected to substantial advantages like in some Western EU countries like UK and France and therefore such minority employee shares has low incidence in Eastern Europe (Hashi m.fl. 2006).

Employees as obligatory members of the boards in large companies are found in The Czech Republic, Slovakia and Slovenia (see table 3). In Czech and Slovakia it may be interpreted as a substitute to the low incidence of employee ownership. In Slovenia on the contrary, it should instead be taken as a complementary system, though there are also some complementarity since they mainly cover large enterprises and here employee ownership is relatively low.

\section{Why did employee ownership become so widespread in some countries?}

Table 4 gives an overview over the most important variables in the analysis. One of the most important reasons for the big variation between the countries is found on the level of society in relation to the level of support for employee ownership in the privatization process. Also the development of different institutions protecting external investor plays an important role for the balance between insider and outsider owners. The progress in the development of financial institutions and the supply of external finance must be included as well. If management can get credit in the bank it may not be necessary to involve the broad group of employees in ownership. The table do not show the political reasons behind the different levels of support for the employees. The political processes are difficult to quantify. However, two important explanations may be suggested. There may be a connection between the political power of the workers and the support for employee ownership. In Lithuania, Poland, Slovakia, Romania and Bulgaria the workers were rather strongly represented by social democratic / labour parties, while Estonia, Latvia, and Croatia were dominated by nationalist agendas, which put economic compensation to the population/employees in the background.

The difference between the development in Estonia and Latvia on one side and Lithuania on the other is a good illustration. The main difference is related to the large Russian speaking minority in 
Estonia and Latvia. This group grew big during the Soviet occupation after the Second World War. In the end of the 1980es before the full independence in 1991 the Russian speaking population was an important alliance partner. Privatization with employee control moved the power from Moscow to the local level. But most of the blue collar workers were Russian speaking, so the control with the companies was transferred to the Russian part. After 1991 the political agenda was dominated by the question of consolidation of the Estonian and the Latvian speaking population. The Russian speaking part lost power and they were not given voting rights at the national elections. Therefore, the privatization models were quickly changed cutting away the support for employee ownership. Lithuania on the contrary had no substantial Russian immigration after the World War. The biggest minority is from Poland. Therefore, the early reform plans from before the full independence were further developed in the years after 1991. The labour-party came back to power in 1992/93 and the large privatization in Lithuania increased the advantages for employee ownership in the first big wave of privatization up to 1995 (Mygind, 2000).

The Polish unions and the relatively strong labour parties are probably important explanations for the support of employee ownership in Poland. The strength of the unions is in fact an exception compared to the rest of Eastern Europe. Except for Poland the established unions were seen as part of the Communist repression of all types of opposition. They had low legitimacy and the number of members fell steeply after the political changes. New unions were organized, but they were also quite weak. In total the unions were very weak in Eastern Europe. In Czechoslovakia there was in the early stage a fight between the left wing and the market liberal wing who found support for employee ownership as a distortion of the market mechanism. In the Czech part the liberals, led by Vaclav Klaus, won the election in 1992 while Meciar won on a populist program in Slovakia. However, in spite of the promises the employees were not favorized in the remaining privatization. Instead Meciar's closest supporters took over some of the firms. Both in Croatia and Slovenia the labour parties were quite weak, but the tradition from the Yugoslav self-management system played a role for the political process. In Croatia the early support for conversion of social ownership to employee ownership were broken by the civil war and were not revived later. This was on the contrary the case in Slovenia, where the internal privatization at the advantage of the employees became quite widespread. Hungary had heavy needs for revenue for the state budget in connection with privatization. This excluded both voucher privatization as well as give-aways to the employ- 
ees. Therefore, there was only the limited support for the relatively small groups of ESOPs included in the Hungarian privatization.

In those countries with considerable support for employee takeovers in privatization - Lithuania, Poland, Romania and Slovenia employee ownership became widespread and the number of new employee owned firms followed the time-pattern of the support. There were in this way strong advantages for employees in the early small privatization in Estonia and Latvia and thus a high frequency of employee ownership in these firms. In the Czech Republic and Slovakia with no advantages for employee ownership there were nearly no companies of this type. In countries with limited support like in Bulgaria there was a similar limited incidence of majority employee ownership. In Hungary the ESOPs had some importance especially in the early stage, but as a share of the total employee ownership had only limited importance in Hungary.

Weak institutions for corporate governance and low developed financial sector may give external owners a relatively weak position in relation to management. Therefore, even without favourable privatization models, insider ownership had some advantages compared to external ownership. At the same time the slow development of the financial sector gave incentives for management to include the broad group of employees in ownership so there were more shoulders to rise the necessary capital. However, it does not seem like it was in countries with weak institutions and a weak financial sector where employee ownership were strongest. Croatia, Slovenia and partly Poland are counter examples. Thus, it can be concluded that the support in the privatization process is the moe important factor for the spread of employee ownership.

There is a clear connection between the special types of firms which were favorized and the development of employee ownership. When the support was focused on small firms like in Estonia and Latvia employee ownership basically only occurred in this group. In Latvia there was, however, also a group of medium sized companies leased to the employees. This was also the case in Poland. In other countries with limited levels of support per employee the employees were not able to takeover firms with high capital intensity. Lithuania was an exception because the support through the first right to buy and the vouchers meant that they were able also to take over quite capital intensive firms. Here was a significant difference compared with Estonia and Latvia (Mygind, 2000). There is no data for the degree of knowledge intensity in different firms. Data from the Baltic countries, 
however, do not indicate a strong positive relation between knowledge intensity and introduction of employee ownership. The highest frequence of employee ownership was in Estonia found in agriculture.

The variables at the individual level cover culture, income and unemployment. There is a close link between the individual and society levels for these variables - they are in fact measured at the macro level as the average yearly income in Euro and as unemployment rates. The income level in Slovenia lies considerably over the other countries, while Bulgaria and Romania is at the bottom. In the overview in table 4 this has been categorized as high and low, while the Baltic countries because of the strong growth over the period are given as low to medium. There is no clear connection between the spread of employee ownership and income levels. The Czech Republic with relatively high wages has not more employee owned companies. This indicates that the lacking advantages in the privatization process has had stronger effect. It also seems that high unemployment is not a strong explanatory factor. Then Slovakia should have a higher incidence. There is no data to check whether high unemployment in peripheral areas has pushed defensive employee takeovers. The high unemployment in Croatia may have played a role for the start of some of the ESOPs.

The special case about Croatia is the fact that these firms were started without special support. Why did this happen in Croatia and not in Slovakia? A possible explanation may be found in the experience and specific culture for employee participation which developed in the Northern parts of former Yugoslavia. This may explain strong employee involvement even without financial support. In Slovenia the strong tradition for employee participation may both have influenced the political processes as well as the individual choices of buying employee shares. In this connection it is worth noting that management takeovers of employee owner firms have been very rare and this explains why employee ownership has been more stable in Slovenia than e.g. in the Baltics (Mygind et al 2006).

\section{Why was employee ownership short lived in most East European countries?}

In general there has been a fall in the frequency of employee ownership in all the nine countries where privatization initially led to many employee takeovers. There is not evidence behind the claim that employee owned companies were closed down or taken over because of low efficiency (Jones, 2004). As explained in the theoretical section a relevant hypothesis is, that the support in 
privatizations resulted in higher frequency of employee ownership than the conditions on society-, company-, and individual levels would otherwise imply. The employees got offers they could not refuse even if they did not have strong desires for ownership and even if they did not have high enough income and wealth to become owners. Therefore, they quickly sold their shares especially to management. At the same time there was a fast institutional development and the financial sector grew up. This improved the possibilities for concentrated ownership both for management and for external owners. Countries with the biggest mismatch between the actual spread of and the conditions for employee ownership can then be expected to have the fastest fall in the number of employee owned companies.

Table 4 Overview over key variables behind the development of employee ownership (EO)

\begin{tabular}{|l|c|c|c|c|c|c|c|c|c|c|}
\hline & \multicolumn{3}{|c|}{ society } & \multicolumn{2}{c|}{ company } & \multicolumn{3}{c|}{ individual } & \multicolumn{2}{c|}{ EO development } \\
\hline & $\begin{array}{c}\text { EO priv. } \\
\text { advantages }\end{array}$ & $\begin{array}{c}\text { insti- } \\
\text { tutions }\end{array}$ & finance & EO size & $\begin{array}{c}\text { EO } \\
\text { C/L }\end{array}$ & culture & income & $\begin{array}{c}\text { unemploy- } \\
\text { ment }\end{array}$ & $\begin{array}{c}\text { EO } \\
\text { number }\end{array}$ & $\begin{array}{c}\text { EO } \\
\text { fall }\end{array}$ \\
\hline Bulgaria & nogen & low & low & small & low & - & low & high-med & few & fast \\
\hline Croatia & + at start & low & medium & + large & low & + & medium & high & ESOP & slow \\
\hline Czech Rep & none & high & medium & 0 & - & - & medium & medium & 0 & - \\
\hline Estonia & + at start & high & high & small & low & - & low-med. & med-low & few & fast \\
\hline Hungary & ESOP & high & high & small,med & low & $(+)$ & medium & medium & few & slow \\
\hline Latvia & + at start & medium & medium & small & low & - & low-med. & high-low & few & fast \\
\hline Lithuania & important & medium & medium & + large & high & - & low-med. & high-low & frequent & fast \\
\hline Poland & important & medium & high & small,med. & low & $(+)$ & medium & high & medium & medium \\
\hline Romania & high ESOP & low & low & small,med. & low & - & low & medium & frequent & slow \\
\hline Slovakia & none & medium & medium & 0 & - & - & low-med. & high & 0 & - \\
\hline Slovenia & important & high & medium & small,med. & low & + & high & med.-low & frequent & slow \\
\hline
\end{tabular}

Lithuania is a good example of such a mismatch. At the level of society there was considerable support for employee ownership, which was widespread also in large and capital intensive firms. At the same time a paternalistic management style prevailed. The employees had no experience in participating in management and thus no desire for such participation. The big fall in production in the first years of transition resulted in very low real wages at the time the employees had taken over their enterprises. Unemployment was high and increasing, but apparently this did not play a strong role for sustaining employee ownership. Large size and high capital intensity implied extra pressure for change of ownership. In Estonia there was in fact observed a faster change in capital intensive enterprises (Jones, Kalmi \& Mygind, 2005). A deeper study of changes in ownership in a large representative sample of Baltic firms show a fast change in ownership structure - often following the 
sequence: employee ownership - management ownership - concentrated external ownership (Jones \& Mygind, 2006). This development is named as fast in the last column in table 4. A high number of case-studies in the Baltic countries show how management could take over the shares at a quite low price because they de facto controlled the company through paternalistic management. The employees did not know the real value of their shares and management could often buy the shares at the nominal price which because of high inflation and the upturn in the economy was way below the real market value. At the same time managers could because of the improving economy and the development of the financial markets find new finance for their takeover (Mygind \& Kalmi, 2007).

Slovenia is a counter-example. Here, there was also a high frequency of employee ownership, but in contrast to Lithuania this was to a higher degree in accordance with the conditions for sustainable employee ownership: There was a workplace culture based on employee participation, a desire for ownership combined with a relatively high income level. At the same time employee ownership was especially widespread in smaller and quite labour intensive firms. Although, because of the advantages in privatization, there was a certain saturation of employee ownership, the fall was much slower than in the Baltics.

In the Baltic countries you find a faster development in Estonia than in Latvia and Lithuania. This may be explained by a somewhat faster development of institutions and the financial sector (Jones \& Mygind, 2006). In general the experience with employee participation in countries like Slovenia and Croatia and to some degree also Poland and Hungary caused a higher stability of employee owned firms. The ESOP format with a certain element of collective ownership may imply, that the sale of individual employee shares is considerably slowed down. This may explain the relatively slow fall in Romania.

\section{Conclusion}

Special conditions gave good starting condition for employee ownership in the first years of transition in Eastern Europe. In the official political rhetoric in the old command economies the workers owned the means of production. This was in sharp contrast to the reality where a small elite controlled the state owned enterprises. In the new market economy a decentralized type of employee ownership could be implemented. This ownership structure was supported by broad groups of the population. This was a main reason why privatization with advantages for the employees was an 
important part of the early models of privatization in countries like Lithuania, Poland, Romania and Slovenia. In countries like Estonia and Latvia the support for employee takeovers were limited to small and medium sized enterprises. In the Czech Republic and Slovakia there was no support for employee ownership.

A closer analysis of the connection between the support at the level of society and the special conditions at the level of company and of the individual level shows that the main explanation behind the spread of employee ownership is the support of employee takeovers in the privatization process. Other factors such as the existence of a special culture for employee participation played also a certain role, but such experience had especially a role for the sustainability of the ownership structure. While employee owned firms changed ownership quite fast in the Baltic countries and in Bulgaria the fall in the numbers were considerably slower in Slovenia, Croatia, Poland and Hungary, where there was more experience with employee participation. The relative high income level in Slovenia may also have played a role while high unemployment which could promote defensive employee takeovers and prolong employee ownership did not seem to have been important.

There is in some countries recent tendencies for a higher frequency of employee ownership in the most modern and often foreign owned firms, but there has not yet been found evidence for higher frequency and development of employee ownership in the most knowledge intensive enterprises. The analysis shows that the spread of employee ownership - except for Slovenia - has happened before the transition economies have been mature enough for the ownership structure. However, the transition and the catching up process is going on with high growth and fast upgrading of production in these years. This growth and the continuous development of the knowledge based economy can be expected to result in new growth in the number of employee owned firms in the coming years. 


\section{Literature}

Albu, Lucian \& Axel Bormann (2006), Romania - extended country report no. XI in Lowitzsch (2006).

Bartlett, Will \& Milica Uvalic (1986) Labour-managed firms, employee participation and profitsharing - Theoretical perspectives and European experience, Management Bibliographies \& Reviews, Vol 12, no. 4.

Blair, Margareth (1995), Ownership and control: rethinking corporate governance for the twentyfirst century, Brookings Institution, Washington D.C.

Boda, Dorottya, László Neumann and Zoltan Vig (2006), Hungary - extended country report no. VI in Lowitzsch (2006).

Brnabić, Ratko, Srečko Goić \& Darko Završak (2006), Croatia - extended country report no. II in Lowitzsch (2006).

Darskuviene, Valdone, Stefan Hanisch \& Niels Mygind (2006), Lithuania - extended country report no. VIII in Lowitzsch (2006).

Dow, Gregory K. (2003), Governing the Firm: Workers' Control in Theory and Practice, Cambridge University Press, West Nyack, NY.

EBRD (2006), Transition Report 2006, London.

Eamets, Raul, Niels Mygind \& Natalia Spitsa, (2006), Estonia - extended country report no. V in Lowitzsch (2006).

Earle, John S. \& Telegdy, Álmos (2002), Privatization Methods and Productivity Effects in Romanian Industrial Enterprises, Central European University Labour Project, Budapest.

Frydman, Roman, Andrzej Rapazynski \& John Earle (1993), The Privatisation Process in Russia, Ukraine and the Baltic States, Central European University (CEU) Privatisation Reports, Vol. II, Budapest, London and New York.

Goecken, Christine, Lubomír Lízal \& Alexander Klein (2006), Slovakia - extended country report no. XII in Lowitzsch (2006).

Gregoric, Aleksandra \& Sime Ivanjko (2006), Slovenia - extended country report no. XIII in Lowitzsch (2006).

Hansmann, Hans (1996) The Ownership of Enterprise, Cambridge, MA., The Belknap Press of Harvard University Press.

Hashi, Iraj, Jens Lowitzsch, Milica Uvalic \& Daniel Vaughan-Whitehead, D. (2006), 'PEPPER III: An Overview of Employee Financial Participation', pp 17-45 in Lowitzsch (2006). 
Heidenhain, Stephan, Lubomír Lízal \& Ondřej Vychodil (2006), Czech Republic - extended country report no. IV in Lowitzsch (2006).

Højrup, Thomas (1983): Det glemte folk: livsformer og centraldirigering, Statens Byggeforskningsinstitut, København.

Ivanova, Stela \& Spartak Keremidchiev (2006), Bulgaria - extended country report no. I in Lowitzsch (2006).

Jarosz, Maria (ed.) (2000), Ten Years of Direct Privatisation, Warsaw: ISP PAN.

Jelušić, Adriana \& Joze Perić (1999), 'Majority of the Employee's Ownership in Croatian Enterprises (Foundations, Characteristics and Prospects)' in Third International Conference on 'Enterprise in Transition', Proceedings, Faculty of Economics Split, Šibenik, 27-29 maj, pp. 1129-1159.

Jones, Derek (2004), 'Ownership and participation: a review of empirical evidence for transition economies' i Perotin \& Robinson, red: Employee participation, firm performance and survival, pp 171-209, Elsevier, Amsterdam.

Jones, Derek, Panu Kalmi \& Niels Mygind (2005), 'Choice of Ownership Structure and Firm Performance: Evidence from Estonia', Post-Communist Economies, Vol 17, no 1.

Jones, Derek \& Niels Mygind (2002) Ownership and Productive Efficiency - evidence from Estonia - Review of Development Economics, vol 6, nr 2 pp. 284-301.

Jones, Derek \& ,Niels Mygind (2006), 'Corporate governance cycles during transition: theory and evidence from the Baltics', ch. 14, pp. 253-286 in The Life Cycle of Corporate Governance, red. Igor Filatotchev \& Mike Wright, Edward Elgar Press, Cheltenham UK.

Kaarsemaker, Eric C. A. \& Eric Poutsma (2006), 'The Fit of Employee Ownership with Other Human Resource Management Practices: Theoretical and empirical suggestions regarding the existence of an ownership high-performance work System', Economic and Industrial Democracy 27(4): 669-685

Klauberg, Theis, Tatyana Muravska \& Niels Mygind (2006), Latvia - extended country report no. VII in Lowitzsch (2006).

Kotrba, Josef (1997), 'The Demise of Employee Ownership in the Czech Privatization Programme?’ i Uvalić \& Vaughan-Whitehead (1997) pp. 120-135.

Kozarzewski, Piotr (2002), Changes in Corporate Governance Structures in Polish Privatised Companies, Centre for the Study of Economic and Social Change in Europe, Working Paper no. 8, London: School of Slavonic and East European Studies, University College London

Kruse, Douglas L. \& Joseph Blasi (1997), 'Employee ownership, employee attitudes, and firm performance: A review of the evidence', in Lewin, D. et al. (eds), The Human Resource Management Handbook, Part 1, JAI Press, Greenwich, CT.

Lowitzsch, Jens (red) (2006), 'The PEPPER III Report: Promotion of Employee Participation in Profits and Enterprise Results in the New Member and Candidate Countries of the European Un- 
ion', EU Commission and Inter-University Centre Split/Berlin, Free University of Berlin, Rome/Berlin.

Lowitzsch, Jens \& Richard Woodward (2006), Poland - extended country report no. X in Lowitzsch (2006).

Meade, James E. (1972), 'The Theory of Labour-managed Firms and Profit Sharing', Economic Journal 82: 402-28.

Mygind, Niels (1987), 'Are Self-managed Firms Efficient?' in Advances in the economic analysis of participatory and labour managed firms, vol 2., Jai Press, pp 243-323 Greenwich, CT.

Mygind, Niels (1994), Omvceltning in Øst, Samfundslitteratur, København.

Mygind, Niels (1994), 'The Economic Transition in the Baltic Countries - Differences and Similarities' in The Politics of Transition in the Baltic States - Democratization and Economic Reform Policies, J. A. Dellenbrant \& O. Nørgaard (red.), Umeå University Research Report, no. 2, Umeå, pp. 197-234.

Mygind, Niels (2000), 'Privatization, Governance and Restructuring of Enterprises in the Baltics', working paper, CCNM/BALT(2000)6: 1-83, OECD, Paris.

Mygind, Niels (2001), Enterprise Governance in Transition - a Stakeholder Perspective. Acta Oeconomica, vol 51, pp 315-342

Mygind, Niels, Natalia Demina, Aleksandra Gregoric \& Rostoslav Kapeliushnikov (2006) 'Corporate governance cycles during transition - A comparison of Russia and Slovenia', Journal of Corporate Ownership and Control, issue 4, volume 3, Summer 2006.

Mygind, Niels \& Panu Kalmi (2007), Privatization and Evolution of Ownership and Corporate Governance - case studies from the Baltic Countries. Copenhagen Business School.

Neersø, Peter (1982): Jugoslavien - socialisme og selvforvaltning i praksis, København, Socialistiske Økonomers Forlag.

Pérotin, Virgine \& Andrew Robinson (2003), Employee participation in profit and ownership: A review of the issues and evidence, European Parliament, Working paper 02-2003, Luxembourg.

Pestoff, Victor (2000), 'Enriching Swedish Women's Work Environment: The Case of Social Enterprises in Day Care', Economic and Industrial Democracy 21(1): 39-70.

Prašnikar, Janez \& Aleksandra Gregoric (2002), 'The Influence of Workers' Participation on the Power of Management in Transitional Countries', Annals of Public and Cooperative Economics, vol 73, pp. 269-297

Prašnikar, Janez \& Jan Svejnar (1998), Investicije, plače in lastništvo v obdobju prehoda v tržno gospodarstvo: Primer slovenskih podjetij [Investment, Wages and Ownership during the Transition to a Market Economy: Evidence from Slovenian Firms], Working Papers Series, No 79, Ljubljana:

Putterman, Louis (1988), 'The firm as association versus the firm as commodity: Efficiency, rights, and ownership', Economics and Philosophy 4(2): 243-266. 
Putterman, Louis (1993), 'Ownership and the Nature of the Firm', Journal of Comparative Economics, 17: 243-263.

Rosen, Corey, John Case \& Martin Staubus (2005), Equity - why employee ownership is good for business, Harvard Business School Press, Boston, MA.

Shiller, Robert J., Maxim Boycko \& Vladimir Korobov (1992), 'Hunting for Homo Sovieticus:

Situational versus Attitudinal Factors in Economic Behavior', Brookings Papers on Economic Activity, no 1.

Simoneti, Marco, Matija Rojec \& Aleksandra Gregoric (2004), Privatisation, Restructuring, and Corporate Governance of the Enterprise sector in Slovenia: From Yugoslavia to European Union, M. Mrak et al. (eds.), Washington DC: The World Bank, pp. 224-244.

Terk, Erik (2000) 'Privatisation in Estonia - ideas - process - results', Estonian Institute for Futures Studies, Tallinn.

Thomas, Henk \& Chris Logan (1982), Mondragon: An Economic Analysis, London, Allen \& Unwin.

Uvalic, Milica (1991), THE PEPPER REPORT: Promotion of Employee Participation in Profits and Enterprise Results in the Member States of the European Community, Social Europe, Supplement 3/91, Commission of the European Communities, Luxembourg.

Uvalic, Milica (2006), 'Employee Ownership - Western Lessons for the Eastern New EU Member States', pp 46-68 in Lowitzsch, 2006.

Uvalic, Milica \& Daniel Vaughan-Whitehead (red.) (1997), Privatisation Surprises in Transition Economies: Employee-Ownership in Central and Eastern Europe, Cheltenham: Edward Elgar.

Vanek, Jaroslav (1971), 'Some fundamental considerations on financing and the form of ownership under labour management', trykt som kap. 8 i 1977, The Labour Managed Economy: Essays by Jaroslav Vanek, Cornell University Press, pp. 171-185, Ithaca, NY.

Whyte, William F. \& Kathleen King Whyte (1991), Making Mondragon: The Growth and Dynamics of the Worker Cooperative Complex, $2 \mathrm{~d}$ edition, ILR Press, Ithaca, NY.

World Bank (2004), Romania: Restructuring for EU Integration - The Policy Agenda. Country Economic Memorandum, Vol. 2: Main Report and Annexes, June, Washington DC 